\title{
PERBEDAAN KEBERHASILAN INSEMINASI BUATAN PADA SAPI ACEH ANTARA DAERAH DATARAN TINGGI DAN DAERAH DATARAN RENDAH DI KABUPATEN PIDIE
}

\author{
Djoko Subagyo $^{(1)}$, Muhammad Jakfar ${ }^{(2)}$ \\ Prodi Peternakan Fakultas Pertanian Universitas Jabal Ghafur \\ Email: djoko.subagyo00@gmail.com
}

\begin{abstract}
ABSTRAK
Penelitian ini dilaksanakan di Kecamatan Tangse dan Kecamatan Glumpang Baro Kabupaten Pidie dari tanggal 10 April sampai 10 Mei 2019. Tujuan dari penelitian ini adalah untuk mengetahui perbedaan keberhasilan inseminasi buatan pada sapi Aceh antara daerah dataran tinggi dan daerah dataran rendah. Diharapkan dari hasil penelitian ini dapat menjadi pedoman dan bahan informasi tentang perbedaan keberhasilan inseminasi buatan pada sapi Aceh daerah dataran tinggi dan daerah dataran rendah.Materi yang digunakan pada penelitian ini adalah sapi Aceh yang berada di wilayah Kecamatan Tangse dan Kecamatan Glumpang Baro Kabupaten Pidie. Data yang diperoleh adalah data primer yang diambil langsung dari inseminator dan peternak. Dari hasil penelitian ini menunjukkan bahwa angka konsepsi didaerah dataran tinggi $64,77 \%$ dan daerah dataran rendah 56,56\%Dari analisa dengan uji t' diperoleh hasil bahwa angka konsepsi antara daerah dataran tinggi dan daerah dataran rendah terdapat perbedaan yang nyata $(\mathrm{P}<0,05)$.
\end{abstract}

Kata kunci : inseminasi buatan, sapi aceh, dataran tinggi, dataran rendah

\section{PENDAHULUHAN}

Pertumbuhan penduduk,
peningkatan pendapatan dan
peningkatan pengetahuan mendorong
meningkatnya kebutuhan protein
hewani. Protein hewani yang
dibutuhkan manusia disediakan dari
tiga sumber yaitu telur, daging dan
susu, protein hewani yang berupa
daging disediakan dari dua sumber,
yaitu temak ruminansia dan ternak
non ruminansia.

Ternak ruminansia terutama sapi potong masih mengalami pertumbuhan yang kurang, sehingga belum dapat mencukupi kebutuhan daging sapi di dalam negeri. Pemerintah berusaha untuk memenuhi kebutuhan daging sapi dengan mengimport ternak hidup dan daging sapi. Masalah tersebut mendorong pernerintah untuk meningkatkan potensi peternakan sapi potong. Pemerintah mengharapkan agar usaha sampingan tersebut dapat dikembangkan menjadi usaha yang bersifat komersial. Wujud program pemerintah ini dinyatakan dengan pemberian dukungan dan pengarahan yang berupa bantuan dalam bentuk kredit, bibit ternak dan penyuluhan. Bibit yang disediakan tidak selalu dalam bentuk ternak, 
tetapi juga dalam bentuk semen beku untuk inseminasi buatan.

Program inseminasi buatan ini merupakan program peningkatan genetik dalam produksi ternak. Sedang yang dimaksud inseminasi buatan sendiri adalah pemasukan atau penyampaian semen kedalam saluran kelamin hewan betina dengan menggunakan alat yang diciptakan manusia( Ihsan, 1992 ).

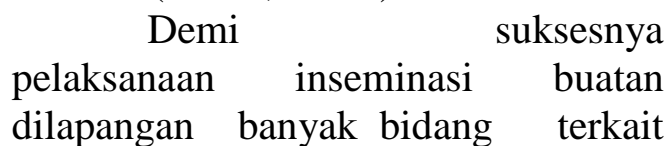
yang harus ditangani karena sama dengan lainnya saling berkaitan dan tidak dapat dilepaskan, khususnya untuk menunjang peningkatan produktifitas ternak. Bidang tersebut antara lain pengetahuan peternak, kemampuan inseminator, ternaknya sendiri serta lingkungan ternak tersebut ( lhsan, 1992 ). Faktor iklim sangat mempengaruhi keberhasilan inseminasi buatan didaerah daerah tropis karena iklim lingkungan mempengaruhi produksi semen. Pada sapi, suhu yang tinggi mempengaruhi motilitas dan jumlah spermatozoa. Goswani dan Nair (1964), setelah mengumpulkan 5 peternakan selama 5 tahun, menyimpulkan bahwa angka konsepsi nyata lebih tinggi apabila suhu udara atau kelembaban menurun, sedangkan suhu yang tinggi berpengaruh negatif terhadap fertilitas. Daerah yang akan digunakan dalam penelitian keberhasilan inserninasi buatan adalah daerah dataran tinggi yang meliputi Kecamatan Tangse. Untuk daerah dataran rendah berada di wilayah kerja kecamatan Glumpang Baro. Kecamatan Tangse
Kabupaten Pidie terletak di propinsi Aceh, memiliki Kelembaban $73-80 \%$ dan temperature $24^{\circ}-29$

- C.Kecamatan Glumpang Baro Kabupaten Pidie terletak di Propinsi Aceh, memiliki kelembaban $60-70 \%$ serta temperature $28^{\circ}-33^{\circ} \mathrm{C}$. Dinas Pertanian dan Peternakan, Bidang PLA, Kabupaten Pidie (2011).

Berdasarkan latar belakang diatas, maka perlu diadakan penelitian tentang perbedaan keberhasilan inseminasi buatan pada sapi Aceh antara daerah dataran tinggi dan daerah dataran rendah.

\section{Rumusan Masalah}

Bagaimana keberhasilan inseminasi buatan pada sapi Aceh antara daerah dataran tinggi dan daerah dataran rendah.

\section{Tujuan Penelitian}

Tujuan dari penelitian ini adalah untuk mengetahui perbedaan keberhasilan inseminasi buatan pada sapi Aceh antara daerah dataran tinggi dan daerah dataran rendah.

\section{Manfaat Penelitian}

Diharapkan dari hasil penelitian ini dapat menjadi pedoman dan bahan informasi tentang perbedaan keberhasilan inseminasi buatan pada sapi Aceh

daerah dataran tinggi dan daerah dataran rendah.

\section{METODE PENELITIAN}

\section{Tempat dan Waktu Penelitian}

Penelitian ini di laksanakan di Kecamatan Tangse dan Kecamatan Glumpang Baro Kabupaten Pidie dari tanggal 10 April sampai 10 Mei 2019.

\section{Materi Penelitian}


Materi yang digunakan pada penelitian ini adalah sapi-sapi Aceh yang berada di wilayah Kecamatan Tangse dan Kecamatan Glumpang Baro Kabupaten Pidie. Data yang diperoleh adalah data primer yang diambil langsung dari inseminator dan peternak.

\section{Metode Penelitian}

Penelitian ini menggunakan metode studi kasus dimana data primer diperoleh dari recording inseminator disertai peninjauan secara langsung.

\section{Variabel yang diamati}

Variabel yang diamati dalam penelitian ini adalah conception rate pada sapi Aceh setelah dilakukan perkawinan dengan inseminasi buatan.

\section{Prosedur Penelitian}

- Pengambilan data dari inseminator berupa data angka konsepsi

- Wawancara Iangsung dengan inseminator ditempat praktek.

- Menghitung kembali data angka konsepsi yang diperoleh

- Mengolah data hasil penelitian.

\section{Analisa Data}

Menurut pendapat Sudjana (1989), bahwa setelah data diperoleh keseluruhan dan dikelompokkan rata-rata hasil dianalisa statistic dengan menggunakan uji t' tidak berpasangan sebagai berikut:

$$
S 1^{2}=\frac{\sum X 1^{2} \frac{\left(\sum X 1\right)^{2}}{n 1}}{n 1-1}
$$

$$
S 2^{2}=\frac{\sum X 2^{2} \frac{\left(\sum X 2\right)^{2}}{n 2}}{n 2-1}
$$

Maka $S 2^{2}$ gabung adalah :

$$
\begin{aligned}
& S 2^{2}=\frac{(n 1-1) S 1^{2}+(n 2-1) S 2^{2}}{(n 1+n 2)-2} \\
& \text { Rumus } \quad \text { uji } \quad t^{\prime} \\
& \mid \mathrm{t} \text { hitung } \mid=\frac{(\overline{X 1}-\overline{X 2})}{\text { Sgabung }} \cdot \sqrt{\frac{n 1 . n 2}{n 1+n 2}}
\end{aligned}
$$

Keterangan:

$\mathrm{n}=$ Jumlah sampel

$\mathrm{Xl}=$ Angka konsepsi IB pada daerah Glumpang Baro

X2 = Angka Konsepsi IB pada daerah Tangse

$X=$ Rata-rata data

S2= Ragam populasi

$\mathrm{S}=$ Simpangan baku

Untuk membandingkan ada tidaknya perbedaan dalam perlakuan maka dibandingkn antara thitung dengan $\mathrm{t}$ tabel sebagai berikut :

- Jika nilai t hitung > t tabel 5\% maka disimpulkan terdapat perbedaan yang nyata - Jika nilai $\mathrm{t}$ hitung > t tabel $1 \%$ maka disimpulkan terdapat perledaan yang sangat nyata - Jika nilai $\mathrm{t}$ hitung $<\mathrm{t}$ tabel $5 \%$ maka disimpulkan tidak terdapat perbedaan

HASIL DAN PEMBAHASAN

Daerah Dataran Tinggi 
Jurnal Sains Riset (JSR)

p-ISSN 2088-0952, e-ISSN 2714-531X

http://journal.unigha.ac.id/index.php/JSR

DOI. $10.47647 /$ jsr.v10i12

Kecamatan Tangse berada di sebelah selatan dari ibu kota Kabupaten Pidie dengan jarak 46 Km. batas utara Kecamatan Tangse adalah Kecamatan Kumala,sebelah barat berbatasan dengan Kabupaten Aceh Besar,sebelah selatan berbatasan dengan Kecamatan Mane dan sebelah timur dengan Kecamatan Meureudu. Ketinggian tempat Kecamatan Tangse $600 \mathrm{~m}$ dpl.

Berdasarkan data yang diperoleh dari Dinas Pertanian dan Peternakan Bidang PLA Kabupaten Pidie, Musim hujan di Kecamatan Tangse antara bulan November sampai April, sedangkan musim kemarau dimulai pada bulan Mei sampai Oktober. Curah hujan tertinggi pada bulan Desember, sedangkan curah hujan terendah pada bulan Agustus. Curah hujan rata-rata per tahun $1820 \quad \mathrm{ml}$. Temperatur di Kecamatan Tangse berkisar antara $24-29{ }^{\circ} \mathrm{C}$. Kelembaban udara antara 73-80\%, kelembaban udara pada musim kemarau dengan musim hujan tidak terlalu jauh berbeda, akan tetapi pada musim hujan sedikit lebih tinggi dibandingkan kelembaban pada musim kemarau.

Disamping untuk diambil dagingnya sebagai tujuan utama, juga sebagai salah satu tabungan bagi peternak.

Kecamatan

Tangse merupakan salah satu daerah yang potensial untuk pemeliharaan sapi Aceh di Kabupaten Pidie. Hal ini dikarenakan oleh dukungan, terutarna tersedia sumber daya alami yang luas sebagai sumber makanan yang berupa rumput-rumputan. Rata-rata pemilikan ternak sapi Aceh adalah 1-3 ekor tiap peternak yang diperoleh dari membeli sendiri dan bantuan dari pemerintah. Umur melahirkan pertama umumnya 2,5-3 tahun, dengan jarak beranak 1,5 tahun Untuk menjarnin kebcrhasilan usaha peternakan rakyat ini, pemerintah secara rutin dan intensif membenkan bimbingan dan penyuluhan lewat petugas lapangan yang ditunjuk. Pemerintah juga telah membangun sarana fisik, yaitu Pos Kesehatan

Hewan. Bentuk pemeliharaan umumnya masih tradisional. Pemberian pakan adalah dengan melepaskan ternak ke lapangan atau dipotongkan (dicarikan) sendiri oleh Peternak. Pemberian makanan pada malam hari hanya, sapi yang sedang bunting tua dan sapi yang kondisinya kurang baik.

\section{Daerah Dataran Rendah}

Kecamatan Glumpang Baro berada di sebelah timur dari ibu kota Kabupaten Pidie dengan jarak $18 \mathrm{Km}$. Batas utara Kecamatan Glumpang Baro adalah Kecamatan Kembang Tanjung, sebelah barat berbatasan dengan Kecamatan Mutiara, sebelah selatan berbatasan dengan Kecamatan Glumpang Tiga dan sebelah timur dengan Kecamatan Bandar Baru. Ketinggian tempat Kecamatan Glumpang Baro 12 mdpl.

Berdasarkan data yang diperoleh dari Dinas Pertanian dan Peternakan Bagian PLA Kabupaten Pidie. Musim hujan di Kecamatan Glumpang Baro antara bulan November sampai April, sedangkan musim kemarau dimulai pada bulan Mei sampai Oktober. Curah hujan tertinggi pada bulan Desember, 
Jurnal Sains Riset (JSR)

p-ISSN 2088-0952, e-ISSN 2714-531X

http://journal.unigha.ac.id/index.php/JSR

DOI. $10.47647 /$ jsr.v10i12

sedangkan curah hujan terendah pada bular Agustus. Curah hujan ratarata per tahun $1185 \mathrm{ml}$. Temperatur di Kecamatan Glumpang Baro berkisar antara 29$34{ }^{\circ} \mathrm{C}$. Kelembaban udara antara 60 $70 \%$.

Sapi Aceh dikembangkan di Kecamatan Glumpang Baro terutama bertujuan untuk diambil dagingnya dan sebagai tabungan dengan dapat dijual sewaktu - waktu. Rata - rata pemilikan ternak sapi Aceh adalah $1-4$ ekor tiap peternak yang diperoleh dari membeli sendiri dan bantuan dari pemenintah. Umur melahirkan pertama umumnya $2-3$ tahun, dengan jarak beranak1,5 tahun. Untuk menjamin keberhasilan usaha peternakan rakyat ini, pemerintah secara rutin dan intensif memberikan bimbingan dan penyuluhan lewat petugas lapangan yang ditunjuk. Pemerintah juga telah membangun sarana fisik, yaitu Pusat Kesehatan Hewan.

Bentuk pemeliharaan umumnya masih tradisional. Pemberian pakan adalah dengan menggiring atau melepaskan ternak di lapangan yang ada rumputnya atau dipotongkan (dicarikan) sendiri oleh Peternak. Pemberian makanan pada malam hari hanya untuk sapi-sapi yang sedang bunting tua dan sapi yang kondisinya kurang baik.

\section{Hasil IB Daerah Dataran Tinggi dan Daerah Dataran Rendah} Pelaksana IB adalah seorang inseminator yang telah berpengalaman demikian juga pemeriksa kebuntingan adalah seorang dokter hewan yang ditugaskan Dinas Pertanian dan
Peternakan Kabupaten Pidie. Banyaknya akseptor IB Kecamatan Tangse selama bulan Juli Desember tahun 2019 adalah 86 ekor dengan jumlah bunting 56 dan angka konsepsi $64,77 \%$,

Untuk daerah Kecamatan Glumpang Baro. Pelaksana IB adalah seorang inseminator yang telah berpengalaman dan pemeriksa kebuntingan adalah seorang dokter hewan yang ditugaskan Dinas Pertanian dan Peternakan Kabupaten Pidie. Banyaknya akseptor IB selama bulan Juli - Desember tahun 2019 adalah 94 ekor dengan jumlah buntirg 55 dan angka konsepsi $56,56 \%$, Untuk mengetahui perbedaan iklim, serta keberhasilan IB antara daerah dataran tinggi dengan daerah dataran rendah dapat dilihat pada tabel berikut. Tabel 1. Data iklim daerah dataran tinggi dan daerah dataran rendah di Kabupaten Pidie.

\begin{tabular}{|c|c|c|}
\hline Iklim & Tangse & $\begin{array}{l}\text { Glumpang } \\
\text { Baro }\end{array}$ \\
\hline Suhu & $24-290$ & $29-34$ \\
\hline Kelembaban & $73-80 \%$ & $60-70 \%$ \\
\hline Curah hujan & $\begin{array}{l}1820 \mathrm{ml} / \\
\text { th. }\end{array}$ & $\begin{array}{l}1185 \mathrm{ml} / \\
\text { th. }\end{array}$ \\
\hline
\end{tabular}

Tabel 2. Data hasil IB di daerah dataran tinggi dan daerah dataran rendah di Kabupaten Pidie.

\begin{tabular}{|l|c|c|}
\hline \multirow{1}{|c|}{ Bulan } & \begin{tabular}{c} 
Glumpang \\
Tangse \\
\cline { 2 - 3 } \\
CR $)$
\end{tabular} & $\begin{array}{l}\text { Baro } \\
\text { CR ( \% }\end{array}$ \\
\hline Juli & 57,14 & 55,33 \\
\hline Agustus & 60,00 & 52.94 \\
\hline September & 64,71 & 52,63 \\
\hline Oktober & 68,75 & 58,82 \\
\hline Nopember & 66,65 & 57,14 \\
\hline
\end{tabular}


Jurnal Sains Riset (JSR)

p-ISSN 2088-0952, e-ISSN 2714-531X

http://journal.unigha.ac.id/index.php/JSR

DOI. $10.47647 /$ jsr.v10i12

\begin{tabular}{|c|c|c|}
\hline Desember & 71,42 & 62,50 \\
\hline Jumlah & 388.62 & 339,36 \\
\hline Rata - rata & 64,77 & 56,56 \\
\hline
\end{tabular}

Dari analisa dengan uji t' diperoleh hasil bahwa angka konsepsi antara daerah dataran tinggi dan daerah dataran rendah terdapat perbedaan yang nyata ( $\quad<0,05)$.

\section{Pembahasan}

Sapi Aceh di Kecamatan Tangse dan Kecamatan Glumpang baro sistem pemeliharaannya masih tradisional dengan dilepas di lapangan. Untuk daerah Kecamatan Tangse sapi dilepas rata - rata masih menggunakan tali hal ini dimungkinkan apabila ada sapi yang sakit atau birahi mudah untuk dikandangkaan. Selain itu ternak sapi digunakan sebagai tabungan dan penghasil daging.

Data pakan yang jelas di Kecamatan Tangse ataupun Glumpang Baro tidak didapatkan, namun berdasarkan pengamatan selama penelitian dan informasi dari para peternak, maka secara kualitatif ataupun kuantitatif pemberian pakan pada sapi daerah Tangse dengan daerah Glumpang Baro hanya untuk memenuhi kebutuhan hidup ternak sedangkan pemberian pakan tambahan pada ternak yaitu saat sapi sakit, bunting tua dan habis melahirkan serta selama musim kemarau. Sehingga berpengaruh pada reproduksi sapi, seperti yang disinyalir oleh Bearden dan Fuguay (1980) bahwa faktor nutrisi sangat diperlukan untuk menjamin keberhasilan reproduksi, yang mencakup energi, protein, vitamin, dan mineral. Defisiensi atau kelebihan salah satu komponen tersebut akan berpengaruh serius terhadap reproduksi, yang selanjutnya akan berpengaruh pada fungsi fisiologis yang lain.

Temperatur yang tinggi untuk daerah Glumpang Baro yaitu 29-34 ${ }^{\circ} \mathrm{C}$ menyebkan sapi melakukan "thermoregulasi" untuk menetralisirnya, sehingga banyak diperlukan air. Konsumsi air yang berlebihan, akan menyebabkan konsumsi pakan berkurang. Sedangkan daerah Tangse temperatur relatif lebih baik yaitu berkisar antara 24-29 ${ }^{\circ} \mathrm{C}$. Menurut Mahdi (1987) pengaruh suhu yang tinggi menyebabkan nafsu makan menurun, sesuai dengan pendapat Tomaszewska dan Putu (1989) bahwa konsumsi pakan sapi akan rendah apabila temperature tinggi. Temperatur juga bisa mempengaruhi reproduksi, sebagaimana pendapat Rao dan Rao (1970), suhu optimum untuk perkawinan sebaiknya antara $28{ }^{\circ} \mathrm{C}$ dan $32{ }^{\circ} \mathrm{C}$, kelembaban nisbi 90- 93\%. Angka konsepsi didaerah Glumpang Baro adalah 56,56\% sedangkan daerah Tangse 64,77\%. Apabila dibandingkan dengan patokan umum angka konsepsi yang normal, yaitu 64\% (Toelihere, 1985), maka angka konsepsi untuk daerah Tangse adalah tergolong normal, sedangkan angka konsepsi pada daerah Glumpang Baro di bawah normal.

Dari hasil perhitungan angka konsepsi dengan uji t didapat hasil $\mathbf{t}$ hitung 3,015 sedangkan $\mathbf{t}$ table $5 \%=$ 2,201 berdasarkan hasil diatas berarti data terdapat perbedaan yang nyata $(\mathrm{P}<0,05)$, dengan demikian angka konsepsi hasil IB di daerah Tangse 
berbeda dengan daerah Glumpang Baro. Perbedaan angka - angka konsepsi tersebut dipengaruhi oleh kondisi lingkungan yang berbedabeda. Hal ini sesuai dengan pernyataan Lindsay et.al,(1982) bahwa proses reproduksi ternak sangat peka terhadap perubahan makan, iklim dan lingkungan sosial ternak tersebut berada. Menurut Partodiharjo (1987) bahwa, rendahnya angka konsepsi disebabkan oleb banyak faktor, seperti faktor lingkungan berupa kekeringan, kurang rumput. Rendahnya angka konsepsi pada daerah Glumpang Baro adalah disebabkan oleh temperatur yang tinggi, yaitu sekitar $29-34{ }^{\circ} \mathrm{C}$ dan kelembaban yang rendah berkisar antara 60\% - 70\%. Hal ini telah dinyatakan pula oleh Hafez (1962) bahwa temperatur kritis sapi adalah $29{ }^{\circ} \mathrm{C}$. Menurut Bearden dan Fuquay (1980), temperature diatas $30^{\circ} \mathrm{C}$ biasanya akan menurunkan angka konsepsi. Williamson dan Payne (1978) menyatakan bahwa suhu yang kritis menyebabkan rendahnya penampilan reproduksi.

Temperatur yang terlalu tinggi menyebabkan sapi menjadi stress panas, untuk mengatasinya maka sapi melakukan thermoregulasi yang banyak memerlukan air. Menurut Toelihere (1981) bahwa sterilitas pada musim panas dapat dikurangi dengan memberi perteduhan dan percikan air. Fungsi air sangat esensial pada musirn kemarau karerna air berfungsi menurunkan panas yang berlebihan, yaitu dengan cara evaporasi pada permukaan kulit, respirasi atau berkeringat. Pada musim kemarau, ke!embaban udara kurang kalau dibandingkan dengan musirn hujan, hal ini menyebabkan sapi sulit menetralisir panas, sehingga menyebabka terganggunya fungsi - fungsi fisiologis (Yasin dan Indarsih, 1988). Akibat lebih lanjut dari stress panas dapat menyebabkan "zona reaction" kurang efisien sehingga lebih dari satu spermatozoa yang masuk ke dalam ovum mengakibatkan embrio tidak normal dan mati (Lindsay et. al, 1982). Berdasarkan cara pemberian pakan yang secara kualitatif ataupun kuantitatif pemberian pakan antara daerah Tangse dengan Glumpang Baro hanya untuk memenuhi kebutuhan hidup ternak sedangkan pakan tambahan hanya diberikan untuk sapi sedang sakit,bunting tua dan musim kemarau. Oleh karena itu seperti yang disinyalir oleh Bearden dan Fuquay (1980) bahwa faktor nutrisi sangat diperlukan untuk menjamin keberhasilan reproduksi, yang mencakup energi, protein, vitamin, dan mineral. Defisiensi atau kelebihan salah satu komponen tersebut akan berpengaruh serius terhadap reproduksi. Tetapi pengkonsumsian pakan yang diberikan peternak akan tidak maksimal apabila suhu lingkungan tinggi karena pada suhu yang tiriggi sapi banyak meminum air sehingga nafsu makan menjadi turun, hal ini sesuai dengan pendapat Mahdi (1987) pengaruh suhu yang tinggi menyebabkan nafsu makan menurun, sesuai dengan pendapat Tomaszewska dan Putu (1989) bahwa konsumsi pakan sapi akan rendah apabila temperatur tinggi. 
Jurnal Sains Riset (JSR)

p-ISSN 2088-0952, e-ISSN 2714-531X

http://journal.unigha.ac.id/index.php/JSR

DOI. $10.47647 /$ jsr.v10i12

\section{KESIMPULAN}

Berdasarkan hasil penelitian ini dapat disimpulkan, bahwa angka konsepsi hasil IB daerah dataran tinggi lebih tinggi dari pada daerah dataran rendah.

\section{DAFTAR PUSTAKA}

Bearden, H. J. and Fuquay, J. W. 1980. Applied Animal Reproduction. Reston Publishing Compony, Inc A Prentice - Hall Compony Reston. Virginia.

Buvanendran,V, E.F.A. Jalatge \& K.N. Ganesan. 1971, Influence of Season on the Breeding Pattern of Buffaloes in Ceylon, Tropical Agriculture.Trinidad.

Dinas Pertanian dan Peternakan Bagian PLA 2011. Kabupaten Pidie.

Goswani, S. B. \&A. P. Nair. 1964. Effect ofSonic Climatologicul Factors on Reproduciion.Indian J. Vet.Sci anim. Husb. 34.

Hafez, E S F. 1987. Reproduction in Farm Animals. Edition.Lea and Febiger. Philadelphia. 5.

Ihsan, N. M. 1992. Inseininasi Buaun.Fakultas Peternakan. Universitas Brawijaya. Malang.

Lindsay, K. W., Entwistle, A. Winantea. 1982. Reproduksi
Ternak di Indonesia Fakultas Peternakan dan Perikanan. Universitas Brawijaya. Malang.

Mahdi, C. 1997. Tingkah Laku Ternak. Uneversitas Brawijaya. Malang

Murtidjo, B.A. 1990. Beternak Sapi Potong. Kanisius.Yogyakarta.

Partodihardjo, S. $1987 . \quad$ Ilmu Reproduk.si Hewan. Mutiara Sumber Widya. Bandung

Raizada, B. C., \& M.D. Pandey. 1972. Reproductive Performance of Buffalo Heifers During Summer. Indian. Anim. Sci. 42.

Rao, A. V. N. \&C. S. Rao. 1970. A Study on Variation In Conception Rate us Influenced by Sire, Season and Age of Semen.Indian vet. 47.

Sastroamidjojo, M.S. 1975. Ternak Potong dan Kerja.CV Yasaguna. Jakarta

Sudjana.1982 Metode Siatistik.Tarsito. Bandung.

Toelihere. M. R. 1981. Inseminasi Buatan pada Ternak. Angkasa. Bandung.

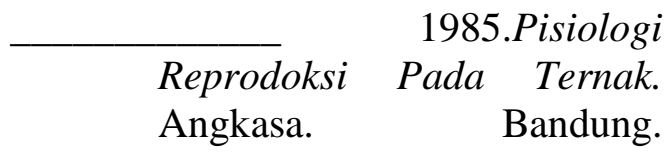

Winantea, . 1987. Reproduksi dan Dasar-dasar Endokrinologi 
Jurnal Sains Riset (JSR)

$p$-ISSN 2088-0952, e-ISSN 2714-531X

http://journal.unigha.ac.id/index.php/JSR

DOI. $10.47647 /$ jsr.v10i12

Pada Hewan Ternak. Yasin, S. dan Indarsih, B. 1988.Seluk NUFFIC-Universitas

Brawijaya.

Malang.

beluk Peternakan Sebuah

Bunga Rampai Anugrah

Karya. Jakarta 